\title{
Floristic Composition of Buah Hitam Habitats in Lowland Tropical Mixed Forest of West Papua, Indonesia
}

\author{
Agustinus Murdjoko ${ }^{1,2, *}$ (C) \\ Antoni Ungirwalu ${ }^{1}$ (D) \\ Zulfikar Mardiyadi ${ }^{1}$ (D) \\ Max Jondudago Tokede ${ }^{1}$ \\ Dony Aristone Djitmau, ${ }^{1,2}$ (D) \\ Nithanel Mikael Hendrik Benu ${ }^{3}$ (D) \\ ${ }^{1}$ Universitas Papua, Fakultas Kehutanan, Jalan Gunung Salju Amban, Manokwari 98314, Papua Barat, Indonesia. \\ ${ }^{2}$ Universitas Papua, Pusat Penelitian Keanekaragaman Hayati (PPKH), Jalan Gunung Salju Amban, Manokwari 98314, Papua Barat, Indonesia. \\ ${ }^{3}$ Balai Penelitian dan Pengembangan Lingkungan Hidup dan Kehutanan (BP2LHK) Manokwari, Jalan Inamberi-Susweni, Manokwari \\ 98301, Papua Barat, Indonesia.
}

\begin{abstract}
The biotic factors in tropical lowland forests, especially vegetation, are essential for the sustainable management of forest products. The study aimed to investigate the species richness and diversity of trees in Buah Hitam habitats, and study the tree communities formed by tree species by collecting the data from the habitats of Buah Hitam in Wondama Bay, West Papua, Indonesia viz. primary forest, secondary, and the garden with plots 9, 9, and 8 respectively. The species richness and diversity were higher in the primary forest than that in the secondary and garden. Tree communities indicated that the primary forest differed from the secondary and garden. The habitat types have been shaped as a result of anthropogenic activities for decades. This finding is necessary to set the consensual programs by the government and local people particularly in conservation and sustainable management for the three habitats.
\end{abstract}

Keywords: Bird's Head Peninsula, Dendrogram, Haplolobus, tree community, PAleontological STatistic

\section{INTRODUCTION}

Understanding the ecological and phytogeographical factors influencing the distribution of diversity in a certain area is imperative (Jung et al., 2020; Pan et al., 2013; Slik et al., 2018). This study focused on tropical forest, as it exhibits hyper diversity under topographical conditions. In addition, the lowland tropical rainforests constitute high biodiversity in terms of the composition of faunal and floral species (Levi et al., 2019; Lugo, 2009). Biodiversity produces some benefits such as the production of timber and non-timber (Villaseñor et al., 2018; Zimmerman \& Kormos, 2012). Therefore, the local community as a social factor has been part of the forest, because they have lived and utilized the forest for generations. Most of these practices are based on their local knowledge, which takes into account the sustainability of the forest as a natural

* email: agustinus.murdjoko.papua@gmail.com resource (Page et al., 2016). By using the method, they have developed traditional concepts of local knowledge for generations. Subsequently, it is part of the interaction between people and forests, in which their livelihood depends on the forest as a natural resource (Armatas et al., 2016; Ungirwalu et al., 2017). Recently, the area in the lowland tropical rainforests is mainly threatened by disturbance, in particular by anthropogenic factors, mainly due to socio-economic development and implemented by the government through empowerment programs, especially in developing countries (Paiva et al., 2020).

Papua is part of the rainforest that contains widespread tropical ecosystems, from coastal to alpine areas (CámaraLeret et al., 2020; Fatem et al., 2020; Kuswandi et al., 2015; Murdjoko et al., 2020, 2021). The local communities have frequently interacted with forests for centuries leading to the development of their knowledge. Non-wood forest products are one of the forest services necessary for their survival, such as nutritional needs, ornamental purposes, etc 
(Cámara-Leret, Raes, et al., 2019; Cámara-Leret \& Dennehy, 2019; Gaveau et al., 2021). The Buah Hitam is a non-wood forest product that has benefited the local Wandamen ethnic groups, in particular, living in the part of the eastern part of the Bird's Head Peninsula in Wondama Bay (Ungirwalu, 2019; Ungirwalu et al., 2016, 2017, 2014). Furthermore, it is taxonomically described as a species of the genus Haplolobus in which the accepted name of Latin botanical names is still debated. The Haplolobus sp was described because the specific morphological characters differed from the accepted species, such as Haplolobus floribundus (K.Schum.) and H.J.Lam Haplolobus monticola Husson. Then, the Buah Hitam was referred to as this species. The traditional use of Buah Hitam has shown the local knowledge of ethno-techno-conservation concepts by ethnic Wandamen (Ungirwalu et al., 2017). This concept is one of the examples of the application of sustainable management by local communities in tropical rainforests. Hence, it is necessary to study the habitat of Buah Hitam by using an ecological approach, with little knowledge of the Buah Hitam ecological habitat.

Ethnic Wandamen grouped the habitats of Buah Hitam in this area, generally in lowland location. Then, the location was divided into three groups based on the information, which are primary forest, secondary forest, and garden (Ungirwalu, 2019; Ungirwalu et al., 2018). All habitats are characterized by the high density of vegetation particularly trees as the main structure. Thus, the environmental condition was different among the habitats, presumably affecting the species guild of tree, species composition, and structure (Murdjoko et al., 2021). Consequently, the ecological process was hypothesized in the three habitats of Buah Hitam varies. Subsequently, this investigation focused mostly on tree species comprising the habitat of Buah Hitam in Wondama Bay. So, the tree structure of floristic diversity, tree species richness, and tree community remained scientifically unknown. Moreover, an understanding of the species composition and species guilds in forest ecosystems is essential in order to set up suitable programs for sustainable forest management.

The specific objectives of this research were to, (1) investigate the species richness and diversity of trees in Buah Hitam habitats, and (2) study the tree communities formed by tree species. The results can be used to support scientific information of non-timber forest product management in tropical rainforest and direct conservation programs based on the traditional concept since the forest is part of the customary forest of ethnic Wandamen.

\section{MATERIAL AND METHODS}

\subsection{Study Area}

This study was conducted in the eastern part of Bird's Head Peninsula and the locations were selected by considering the activity of the local community in utilizing the Buah Hitam (Figure 1). The four areas were selected to place the plots and they were administratively located in four districts of the Teluk Wondama Regency viz. Wasior (Rado, $\left.2^{\circ} 40^{\prime} 18.06^{\prime \prime} \mathrm{S}, 134^{\circ} 30^{\prime} 17.33^{\prime \prime E}\right)$, Wondiboi (Kaibi, $2^{\circ} 48^{\prime} 14.19^{\prime \prime S}$, $\left.134^{\circ} 31^{\prime} 59.08^{\prime \prime E}\right)$, Rasiey (Tandia, $2^{\circ} 50^{\prime} 32.28^{\prime \prime S}, 134^{\circ} 32^{\prime} 31.27^{\prime \prime} \mathrm{E}$ ), and Duari (Sobey, $2^{\circ} 33^{\prime} 16.20^{\prime \prime} \mathrm{S}, 134^{\circ} 28^{\prime} 39.67^{\prime \prime E}$ ). The four locations of the study area were mainly in lowland forest with elevation 24-98 m above sea level and close to the sea in western and northern parts while the southern part was the coastal area of Teluk Wondama Regency (Two districts: Kuri and Idoor) and the eastern part of Wondiwoi Mountains (Nature Reserve) (Ungirwalu et al., 2018). The study area was divided ecologically into three habitats of Buah Hitam namely primary forest, secondary forest, and the garden. The primary forest was the characteristic of the old-growth forest where anthropogenic intervention was infrequent. The secondary forest was a re-growth forest resulting from the fallow swidden whilst garden was the location nearby home with vegetation area formed by utilizing the useful plant grow naturally or artificially without agricultural treatments. The information regarding the Buah Hitam habitats was obtained by applying the Snowball sampling during an interview with local people. The locations were predominantly inhabited by ethnic groups of Wandamen consisting of subethnic groups namely Wamesa, Kuri, Miere, Mairasi/Toro, Ambumi, and Dusner (Ungirwalu et al., 2018). They have been utilizing Buah Hitam as part of their life for generations in which they also apply the local wisdom as part of traditionally sustainable management of Buah Hitam. Most of the local people depend on natural resources for their livelihood, as used by the traditional farmers in swidden (Ungirwalu et al., 2017). 


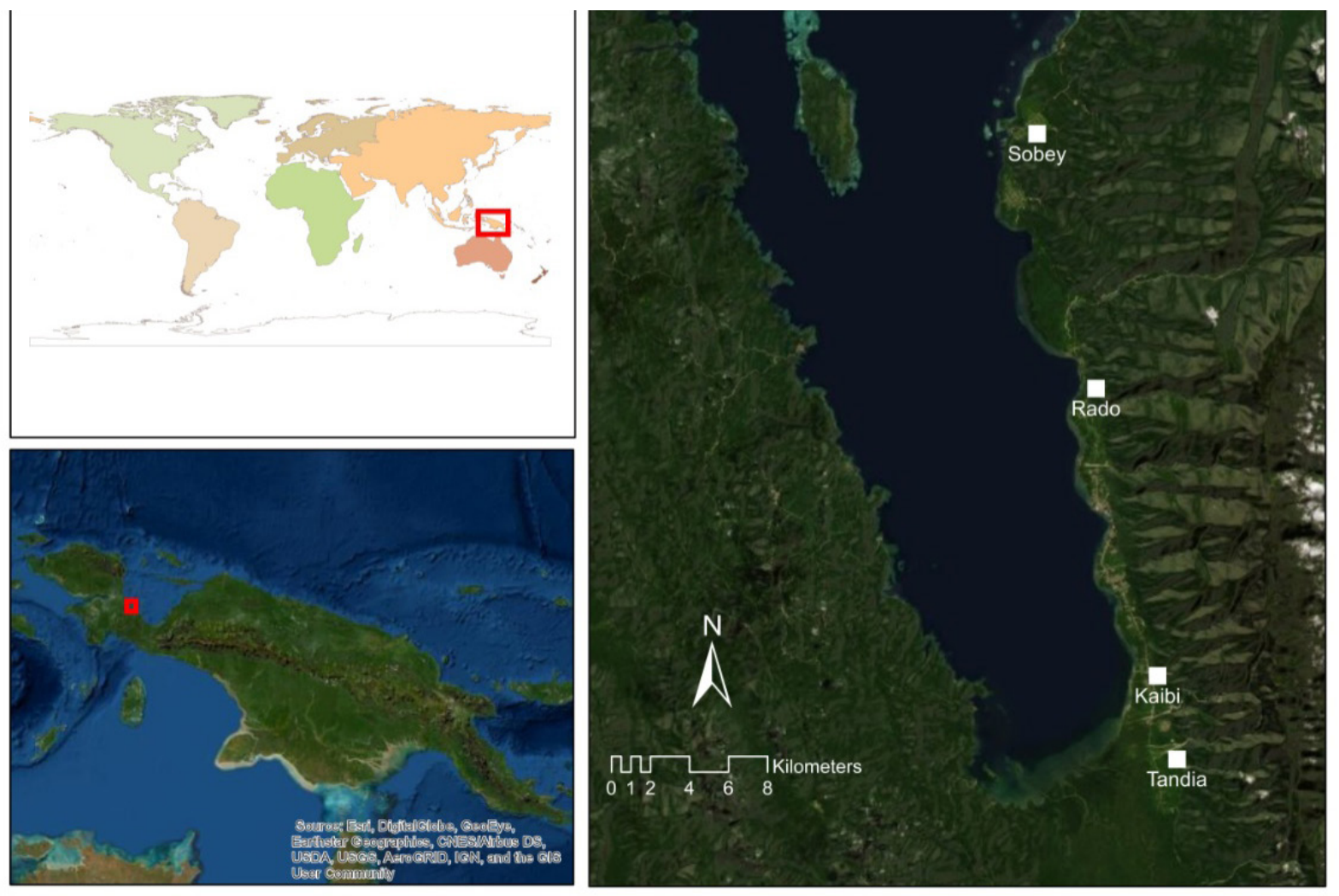

Figure 1. The four locations of the research study on the main map (white boxes).

The locations are mainly characterized by tropical mixed forests with a large number of families and species of vegetation, of which tree species were the main structure (Murdjoko et al., 2021; Ungirwalu, 2019). Alluvial soil was the major species at the sites, with raw organic material ranging from $1.1 \%$ to $2.33 \%$ (C-organic), cation exchange capacity (CEC) was around 5.23-11.56 meq $/ 100 \mathrm{~g}$, nitrogen (N-total) was from 0.12-0.19\% and Soil pH was about 4.51-6.14 (Ungirwalu et al., 2018). The climate data of mean temperature and mean humidity were $26.4^{\circ} \mathrm{C}\left(23.3^{\circ} \mathrm{C}\right.$ and $31.2^{\circ} \mathrm{C}$, minimal and maximum) and $86.4 \%$ (64.4\% and $97.6 \%$, minimal and maximum), respectively (Badan Pusat Statistik Kota Teluk Wondama, 2019).

\subsection{Sampling and vegetation observation}

Twenty-six samples of the plots, which consists of 9 plots in primary forest, 9 plots in secondary, and 8 plots in the garden were placed. The distribution of plots based on locations were Wasior (2 plots for each primary forest, secondary forest, and garden), Wondiwoi (2 plots for each primary forest, secondary forest, and garden), Rasiey (3 plots for each primary forest, and secondary forest, 2 plots in garden), and Duari (2 plots for each primary forest, secondary forest, and garden). The plot size was $20 \mathrm{~m} \times 20 \mathrm{~m}$ for tree data with a diameter above $20 \mathrm{~cm}$ and there were three subplots inside the main plot to collect data of pole as categorized with diameter between 10-20 $\mathrm{cm}(10 \mathrm{~m} \times 10 \mathrm{~m})$, plot with size $5 \mathrm{~m} \times 5 \mathrm{~m}$ was used for the collection of sapling as categorized with a height taller than $1.5 \mathrm{~m}$, and plot with size $2 \mathrm{~m} \times 2 \mathrm{~m}$ was used for the collection of seedling as categorized with the height less than $1.5 \mathrm{~m}$. The plots were set purposively with a minimal distance of at least $100 \mathrm{~m}$ in the habitat of Buah Hitam in primary forest, secondary, and garden. The data was collected in the form of taxonomic information (family and species), the number of individuals, and diameter $(\mathrm{cm})$. The species and family were obtained from voucher identified in Herbarium Papuaense of "Balai Penelitian dan Pengembangan Lingkungan Hidup dan Kehutanan (BP2LHK) Manokwari" and Herbarium Manokwariense (MAN) Pusat Penelitian Keanekaragaman Hayati Universitas Papua (PPKH-UNIPA), Manokwari. The scientific names of the tree were based on The Plant List (TPL) (http://www.theplantlist.org) and Taxonomic Backbone of the World Flora Online (WFO) (www.worldfloraonline.org). 


\subsection{Data analysis}

Tree species richness and diversity. The tree vegetation in the primary forest, secondary, and garden were compared by applying the sample rarefaction (Mao's tau) by setting a matrix of presence-absence data abundance (Taxa $S$ using $95 \%$ confidence). The species accumulation curve was performed to describe the species number in three habitats over the number of individuals (Colwell et al., 2004). The Shannon-Wiener index $\left(\mathrm{H}^{\prime}\right)$ and Pielou's evenness $\left(J^{\prime}\right)$ were implemented to analyze the species richness and evenness (Shannon, 1948; Spellerberg \& Fedor, 2003). The Species abundance curve or Whittaker plot in primary forest was applied to analyze the dominant families and the tree species (Peet, 2007; Whittaker, 1972). The abundance of individuals based on families and tree species was in vertical axis with the rank of families and species in descending order in horizontal axis.

Tree community. The tree species were grouped by executing Dendrogram and discussing the tree species growing along with Buah Hitam. The graphs of individuals of tree species against diameter class $(\mathrm{cm})$ were employed by dividing them into 7 diameter classes with an interval of $10 \mathrm{~cm}$. To depict statistically the relationship between tree density and Buah Hitam density, the linear regression was computed with the correlation, then $95 \%$ of the confidence interval in the regression graph was calculated and shown using tree density as an independent variable and Buah Hitam density as the dependent variable. The multivariate analysis of Correspondence Analysis (CA) was instigated to examine the tree communities by considering the plots of three habitats in two axes on the graph of CA (Vleminckx et al., 2015). The vertical structure of the three habitats was displayed by comparing the density proportion of seedlings, saplings, poles, and trees in the graphs. The data was analyzed by operating the (PAleontological STatistics) software version 4.03 as a freeware data analyzer (Hammer et al., 2001).

\section{RESULTS}

\subsection{Taxonomic richness and diversity in three types of Buah Hitam habitat}

The data were described as 1003 individuals of vegetation, 33 families, and 83 species of trees. The individuals distributed in primary forest, secondary, and garden were 345,381 , and 277 respectively. The highest distribution of taxonomic groups for family was in the secondary forest (26 families), followed by families in the primary forest ( 24 families), and the lowest number of families was in the garden (16 families). There was a decrease in species number from primary forest (53 species), secondary forest (47 species), and garden (25 species) (Figure 3 on the left side). The Sample rarefaction showed the number of species growth with the increase in the number of individuals (Specimens) in three habitats of Buah Hitam (Figure 2). The three species curves displayed the non-linear model in which the growth started early and predictably reached a plateau as optimal species number during the data collection. This investigation focused on tree species as structural vegetation of Buah Hitam habitat in the three locations.

The species richness of the tree vegetation in the tree locations was defined by means of Shannon wiener index $\left(H^{\prime}\right)$, while the species evenness was expressed as Pielou's evenness index (J') shown in Figure 3 on the right side. The tree species richness displayed the decrease between locations of primary forest and secondary and then there was a gradual increase in garden but lower than the primary forest.

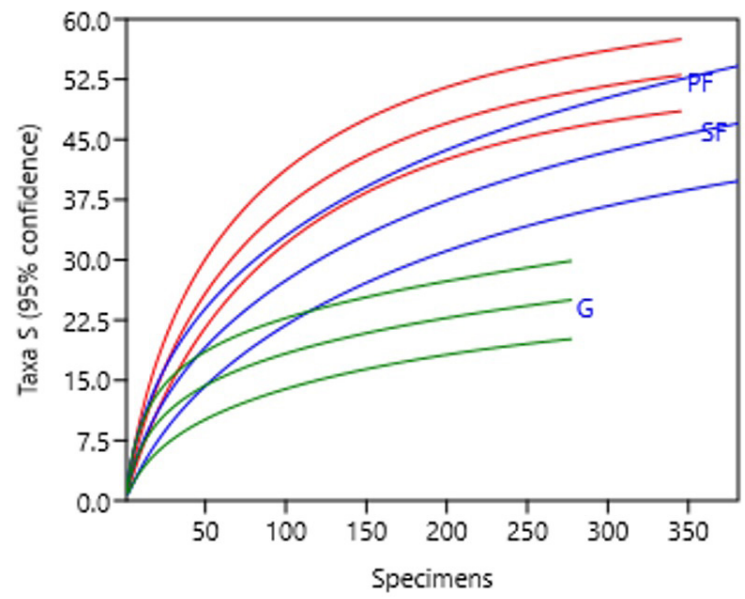

Figure 2. The number of species against the number of individuals (specimens) using Sample rarefaction (Mao's tau) in primary forest $(\mathrm{PF})$ and secondary forest (SF), and Garden $(\mathrm{G})$. The confidence intervals for the three species curve were 95 percent.

Species density was ranked in three habitats in ascending order, as shown in Figure 4. The Haplolobus sp was the dominant species in the three habitats with the variation of density. The dominant family in the three habitats was Burseraceae based on the number of individuals and species (Figure 4). The highest density was in the secondary forest in which the dominant species were more or less than 120 individuals. The dominant species in the garden was about 65 individuals, and the dominant species in the primary forest was approximately 45 individuals. The dominance of families and tree species in three habitats has been shown 
for ten families and species, the composition of which varies between the three locations, as shown in Figure 4 below for the dominant family and above the dominant species. The five dominant families in primary forest were Burseraceae, Sapindaceae, Myristicaceae, Meliaceae, and Moraceae. The top five families in the secondary forest were Burseraceae, Moraceae, Meliaceae, Sapindaceae, and Lamiaceae. The garden was dominantly presented by families of Burseraceae, Sapindaceae, Meliaceae, Anacardiaceae, and Lamiaceae. The five dominant species in primary forest
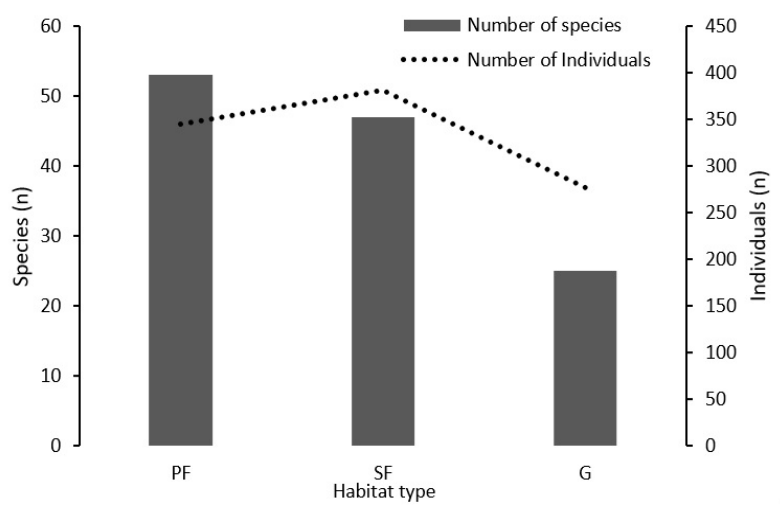

were Haplolobus sp, Artocarpus integer (Thunb.) Merr, Lansium domesticum Corrêa, Litsea timoriana Span and Myristica fatua Houtt. The secondary forest was mainly presented by Haplolobus sp, Artocarpus altilis (Parkinson ex F.A.Zorn) Fosberg, Lansium domesticum Corrêa, Artocarpus heterophyllus Lam., and Mangifera indica L. whilst the species of Haplolobus sp, Lansium domesticum Corrêa, Mangifera indica L, Nephelium lappaceum L, and Syzygium malaccense (L.) Merr. \& L.M.Perry grew predominantly in the garden.

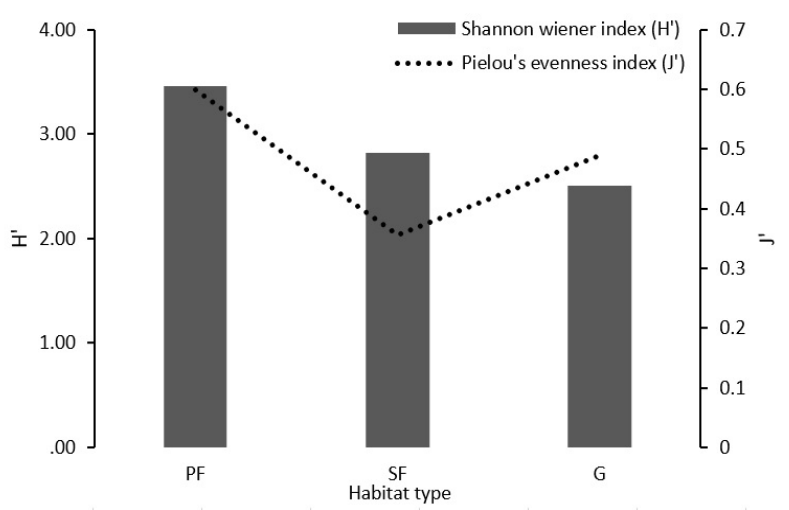

Figure 3. Species and individual number (left) as well as Shannon-Wiener index $\left(\mathrm{H}^{\prime}\right)$ and Pielou's evenness index ( $\mathrm{J}^{\prime}$ ) (right) in primary forest (PF) and secondary forest (SF), and Garden (G). The bar charts use the primary axis (left scale) and the line charts use the secondary axis (right scale).
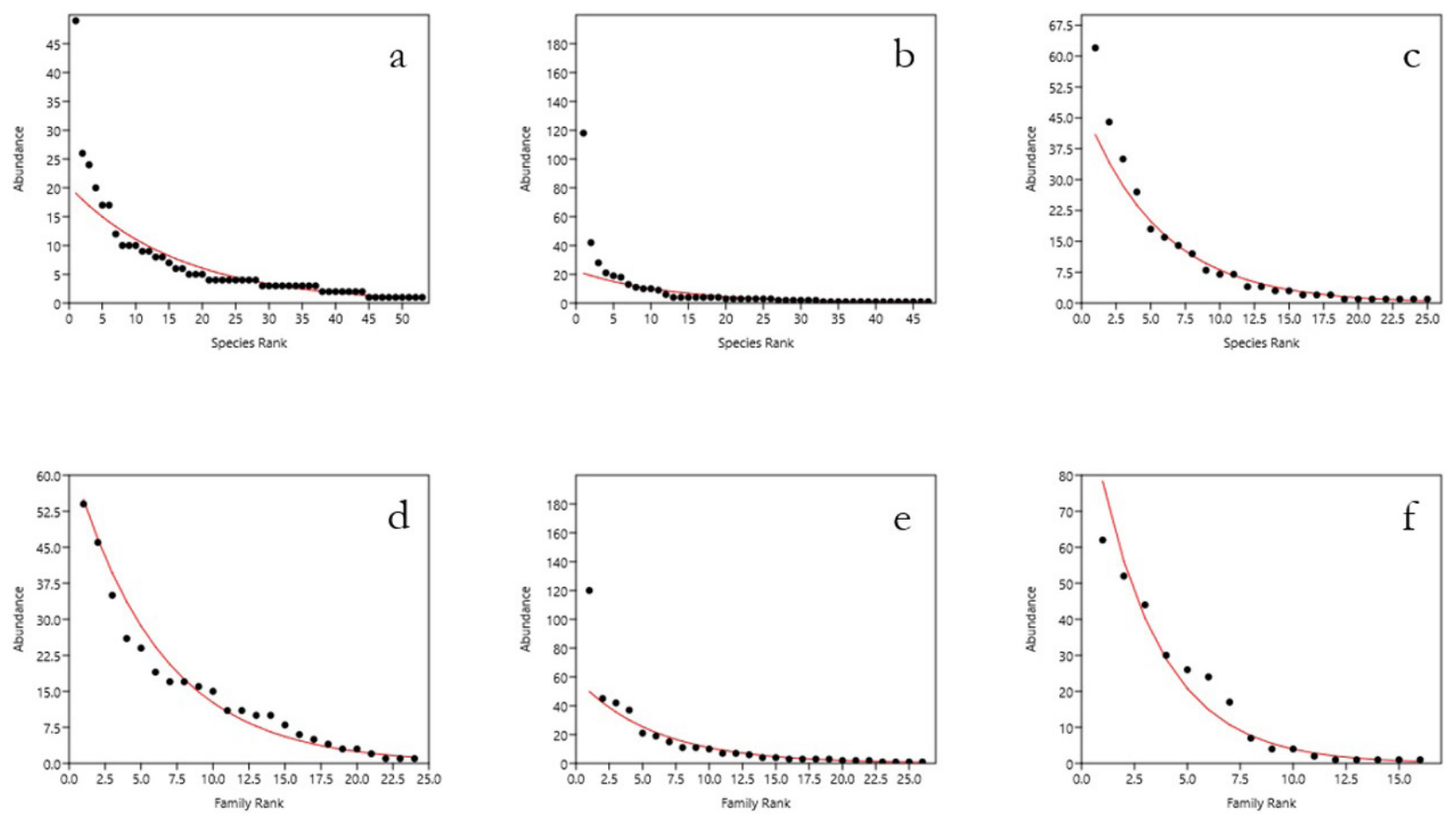

Figure 4. Ranking of the species abundance curve or Whittaker plot in primary forest (a) and secondary forest (b), and Garden (c). The family rank is displayed in primary forest (d) and secondary forest (e), and Garden (f). Y-axis (Abundance) is the relative abundance and $\mathrm{X}$-axis (Rank) is the species and family rank. 


\subsection{Ecological group forming in Buah Hitam habitat}

Tree species in tropical rainforests shaped the tree communities as part of a mixed forest. The groups were presented here using the similarity of Dendrogram regardless of the small and larger individuals. The group of tree species showed the heterospecific association in the three habitats of Buah Hitam.

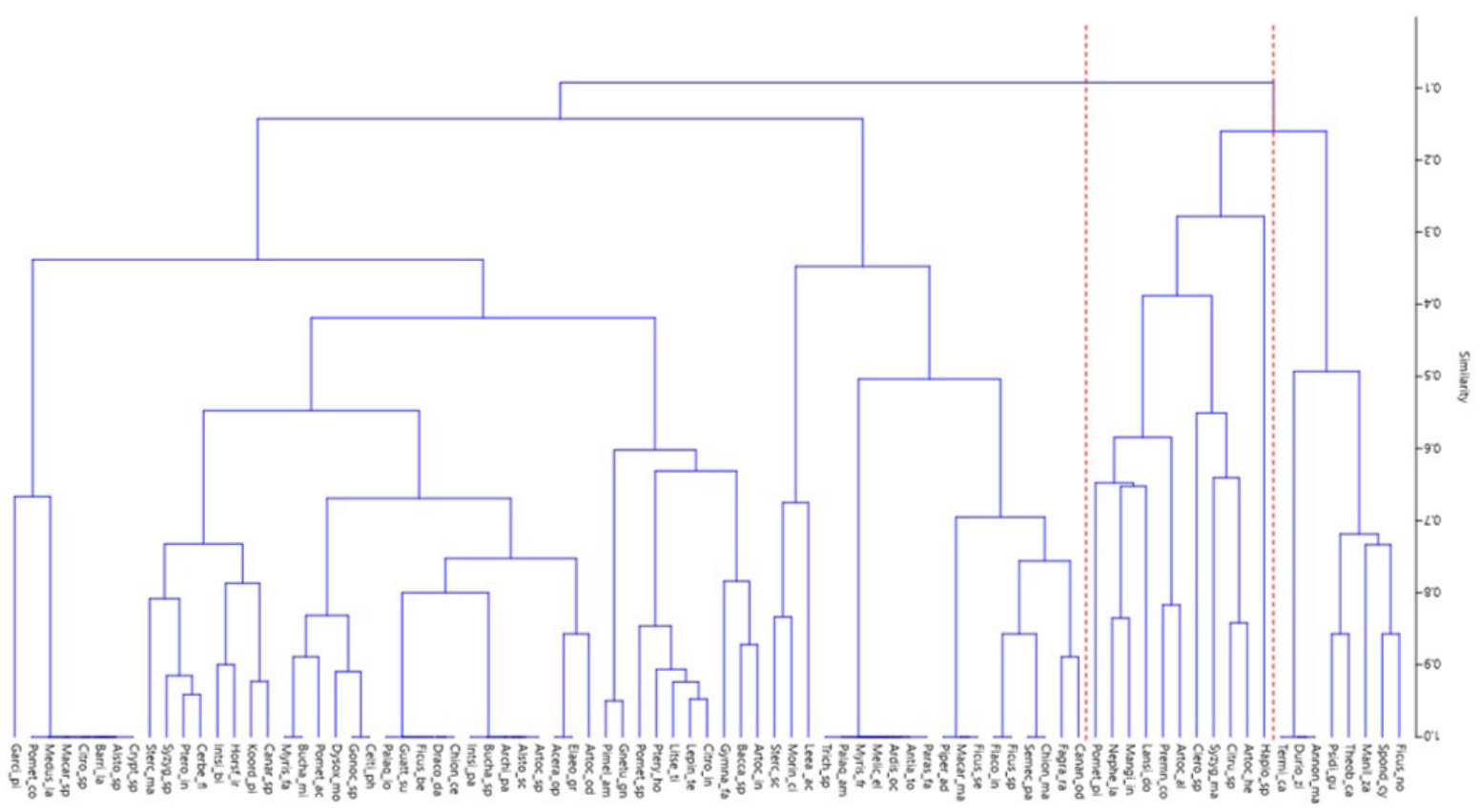

Figure 5. Dendrogram of tree species using similarity index (\%). The ten species between dashed red lines have the same group as Buah Hitam in the three habitats. The abbreviations for species are displayed in Table 1 (Tree Species and Acronym).

Table 1. List of tree species (83) and family (33) in primary forest (PF) and secondary forest (SF), and Garden (G) with number represented as density.

\begin{tabular}{|c|c|c|c|c|c|c|}
\hline No. & Family & Tree Species & Acronym & PF & SF & G \\
\hline 1 & Anacardiaceae & Buchanania sp & Bucha_sp & 2 & & \\
\hline 2 & & Buchanania microphylla Engl. & Bucha_mi & 4 & & \\
\hline 3 & & Dracontomelon dao (Blanco) Merr. \& Rolfe & Draco_da & 3 & & \\
\hline 4 & & Koordersiodendron pinnatum Merr. & Koord_pi & 4 & 2 & \\
\hline 5 & & Mangifera indica $\mathrm{L}$. & Mangi_in & 6 & 13 & 27 \\
\hline 6 & & Semecarpus papuana Lauterb. & Semec_pa & & 3 & \\
\hline 7 & & Spondias cytherea Sonn. & Spond_cy & & 1 & 3 \\
\hline 8 & Annonaceae & Annona manirote Kunth & Annon_ma & & & 1 \\
\hline 9 & & Cananga odorata (Lam.) Hook.f. \& Thomson & Canan_od & 1 & 3 & \\
\hline 10 & & Guatteria sumatrana Miq. & Guatt_su & 3 & & \\
\hline 11 & Apocynaceae & Alstonia scholaris (L.) R. Br. & Alsto_sc & 2 & & \\
\hline 12 & & Alstonia spectabilis R.Br. & Alsto_sp & 1 & & \\
\hline 13 & & Cerbera floribunda K.Schum. & Cerbe_fl & 4 & 3 & 1 \\
\hline 14 & & Lepiniopsis ternatensis Valeton & Lepin_te & 10 & & \\
\hline 15 & Burseraceae & Canarium sp & Canar_sp & 5 & 2 & \\
\hline 16 & & Haplolobus sp & Haplo_sp & 49 & 118 & 62 \\
\hline
\end{tabular}


Table 1. Continued...

\begin{tabular}{|c|c|c|c|c|c|c|}
\hline No. & Family & Tree Species & Acronym & PF & SF & G \\
\hline 17 & Cannabaceae & Celtis philippensis Blanco & Celti_ph & 5 & & \\
\hline 18 & Cardiopteridaceae & Citronella sp & Citro_sp & 1 & & \\
\hline 19 & & Citronella incarum (J.F.Macbr.) R.A.Howard & Citro_in & 9 & & \\
\hline 20 & & Gonocaryum sp & Gonoc_sp & 5 & & \\
\hline 21 & Clusiaceae & Garcinia picrorhiza Miq. & Garci_pi & 1 & 1 & \\
\hline 22 & Combretaceae & Terminalia catappa L. & Termi_ca & & & 1 \\
\hline 23 & Elaeocarpaceae & Aceratium oppositifolium DC. & Acera_op & 3 & 1 & \\
\hline 24 & & Elaeocarpus grandiflorus Sm. & Elaeo_gr & 3 & 1 & \\
\hline 25 & Euphorbiaceae & Macaranga sp & Macar_sp & 1 & & \\
\hline 26 & & Macaranga mappa (L.) Müll.Arg. & Macar_ma & & 2 & \\
\hline 27 & & Pimelodendron amboinicum Hassk. & Pimel_am & 10 & 9 & \\
\hline 28 & Flacourtiaceae & Flacourtia inermis Roxb. & Flaco_in & & 4 & \\
\hline 29 & Gentianaceae & Fagraea racemosa Jack & Fagra_ra & 2 & 3 & \\
\hline 30 & Gnetaceae & Gnetum gnemon L. & Gnetu_gn & 10 & 11 & \\
\hline 31 & Lamiaceae & Clerodendrum sp & Clero_sp & & & 18 \\
\hline 32 & & Premna corymbosa Rottler \& Willd. & Premn_co & & 21 & 8 \\
\hline 33 & Lauraceae & Cryptocarya sp & Crypt_sp & 1 & & \\
\hline 34 & & Litsea timoriana Span. & Litse_ti & 9 & 1 & \\
\hline 35 & Lecythidaceae & Barringtonia lauterbachii R.Knuth & Barri_la & 1 & & \\
\hline 36 & Leguminosae & Archidendron parviflorum Pulle & Archi_pa & 2 & & \\
\hline 37 & & Intsia bijuga (Colebr.) Kuntze & Intsi_bi & 8 & 2 & \\
\hline 38 & & Intsia palembanica Miq. & Intsi_pa & 2 & & \\
\hline 39 & & Paraserianthes falcataria (L.) I.C.Nielsen & Paras_fa & & 1 & \\
\hline 40 & & Pterocarpus indicus Willd. & Ptero_in & 4 & 4 & 1 \\
\hline 41 & Malvacea & Theobroma cacao L. & Theob_ca & & & 4 \\
\hline 42 & Malvaceae & Durio zibethinus L. & Durio_zi & & & 1 \\
\hline 43 & & Pterygota horsfieldii (R.Br.) Kosterm. & Ptery_ho & 8 & & \\
\hline 44 & & Sterculia macrophylla Vent. & Sterc_ma & 3 & 4 & \\
\hline 45 & & Sterculia schliebenii Mildbr. & Sterc_sc & & 10 & \\
\hline 46 & & Trichospermum sp & Trich_sp & & 1 & \\
\hline 47 & Meliaceae & Dysoxylum mollissimum Blume & Dysox_mo & 6 & & \\
\hline 48 & & Lansium domesticum Corrêa & Lansi_do & 20 & 42 & 44 \\
\hline 49 & Moraceae & Antiaris toxicaria Lesch. & Antia_to & & 1 & \\
\hline 50 & & Artocarpus altilis (Parkinson ex F.A.Zorn) Fosberg & Artoc_al & & 28 & 14 \\
\hline 51 & & Artocarpus heterophyllus Lam. & Artoc_he & & 4 & 7 \\
\hline 52 & & Artocarpus integer (Thunb.) Merr. & Artoc_in & 17 & 4 & 1 \\
\hline 53 & & Artocarpus odoratissimus Blanco & Artoc_od & 2 & 1 & \\
\hline 54 & & Artocarpus sp & Artoc_sp & 2 & & \\
\hline 55 & & Ficus sp & Ficus_sp & & 4 & \\
\hline 56 & & Ficus benjamina $\mathrm{L}$. & Ficus_be & 3 & & \\
\hline 57 & & Ficus nodosa Teijsm. \& Binn. & Ficus_no & & 1 & 2 \\
\hline 58 & & Ficus septica Burm.f. & Ficus_se & & 2 & \\
\hline 59 & Myristicaceae & Gymnacranthera farquhariana (Hook.f. \& Thomson) Warb. & Gymna_fa & 24 & & \\
\hline
\end{tabular}


Table 1. Continued...

\begin{tabular}{|c|c|c|c|c|c|c|}
\hline No. & Family & Tree Species & Acronym & PF & SF & G \\
\hline 60 & & Horsfieldia irya (Gaertn.) Warb. & Horsf_ir & 7 & 3 & \\
\hline 61 & & Myristica fatua Houtt. & Myris_fa & 4 & & \\
\hline 62 & & Myristica fragrans Houtt. & Myris_fr & & 1 & \\
\hline 63 & Myrtaceae & Psidium guajava L. & Psidi_gu & & & 3 \\
\hline 64 & & Syzygium sp & Syzyg_sp & 4 & 3 & 2 \\
\hline 65 & & Syzygium malaccense (L.) Merr. \& L.M.Perry & Syzyg_ma & 4 & 4 & 12 \\
\hline 66 & Oleaceae & Chionanthus celebicus Koord. & Chion_ce & 3 & & \\
\hline 67 & & Chionanthus macrocarpus Blume & Chion_ma & & 3 & \\
\hline 68 & Phyllanthaceae & Baccaurea sp & Bacca_sp & 17 & & \\
\hline 69 & Piperaceae & Piper aduncum L. & Piper_ad & & 2 & \\
\hline 70 & Primulaceae & Ardisia ochracea Elmer & Ardis_oc & & 1 & \\
\hline 71 & Rubiaceae & Morinda citrifolia L. & Morin_ci & & 10 & 4 \\
\hline 72 & Rutaceae & Citrus sp & Citru_sp & & 1 & 7 \\
\hline 73 & & Melicope elleryana (F. Muell.) T.G. Hartley & Melic_el & & 1 & \\
\hline 74 & Sapindaceae & Nephelium lappaceum L. & Nephe_la & 3 & 19 & 35 \\
\hline 75 & & Pometia acuminata Radlk. & Pomet_ac & 4 & & 1 \\
\hline 76 & & Pometia coriacea Radlk. & Pomet_co & 1 & & \\
\hline 77 & & Pometia pinnata J.R. Forst. \& G. Forst. & Pomet_pi & 26 & 18 & 16 \\
\hline 78 & & Pometia sp & Pomet_sp & 12 & & \\
\hline 79 & Sapotaceae & Manilkara zapota (L.) P.Royen & Manil_za & & & 2 \\
\hline 80 & & Palaquium amboinense Burck & Palaq_am & & 1 & \\
\hline 81 & & Palaquium lobbianum Burck & Palaq_lo & 3 & & \\
\hline 82 & Stemonuraceae & Medusanthera laxiflora (Miers) R.A. Howard & Medus_la & 1 & & \\
\hline 83 & Vitaceae & Leea aculeata Blume ex Spreng. & Leea_ac & & 6 & \\
\hline
\end{tabular}

The formation of the tree community here is focused on the tree species growing around Buah Hitam species (Figure 5) and the acronyms of tree species were shown in Table 1 . The result showed that ten species had a strong relation with Buah Hitam namely Artocarpus heterophyllus Lam., Citrus sp, Sterculia schliebenii Mildbr., Clerodendrum sp, Artocarpus altilis (Parkinson ex F.A.Zorn) Fosberg, Premna corymbosa Rottler \& Willd., Lansium domesticum Corrêa, Mangifera indica L., Nephelium lappaceum L., and Pometia pinnata J.R. Forst. \& G. Forst.

The individuals of tree species showed the reverse J-shaped model in the tree habitats of Buah Hitam (Figure 6 a). The individuals of tree species were distributed from small diameter to more or less $60-69 \mathrm{~cm}$, unless for individuals in the garden in this class diameter, which was missing. In contrast, the distribution of individuals of Buah Hitam in the three habitats did not follow the reverse J-shaped model, but there was the availability of Buah Hitam in almost class diameter except the diameter larger than 50 in garden habitat. The regeneration of Buah Hitam was running well as the number of individuals of small and larger was available even though the number of individuals was not abundantly distributed (Figure $6 \mathrm{~b}$ ).

Figure 7 showed that the equation model was described linearly as $y=0.0988 x+6.1845$, where the indicated $y$ was a dependent variable and $\mathrm{x}$ was the symbol for the independent variable. The contribution of tree density to the number of Buah Hitam density was explained statistically using a coefficient of determination $\left(\mathrm{R}^{2}\right)$, in which about $40 \%$ of the distribution of Buah Hitam density was expressed by tree density in the three habitats. Furthermore, $95 \%$ of the confidence interval was applied to the linear regression as shown when the blue lines explained the upper and lower limit.

The Correspondence Analysis has displayed the tree communities form in the habitat of Buah Hitam as illustrated in Figure 8. The plots of primary forests seem to be distributed by creating groups unless one plot joining another group, while the plots of secondary forest and garden tend to constitute a group except for one plot of the garden. The first axis (Axis 1) explained $13.9 \%$ of the variation in this model while the second axis (Axis 2) described $9.94 \%$ of the variation of this model. 

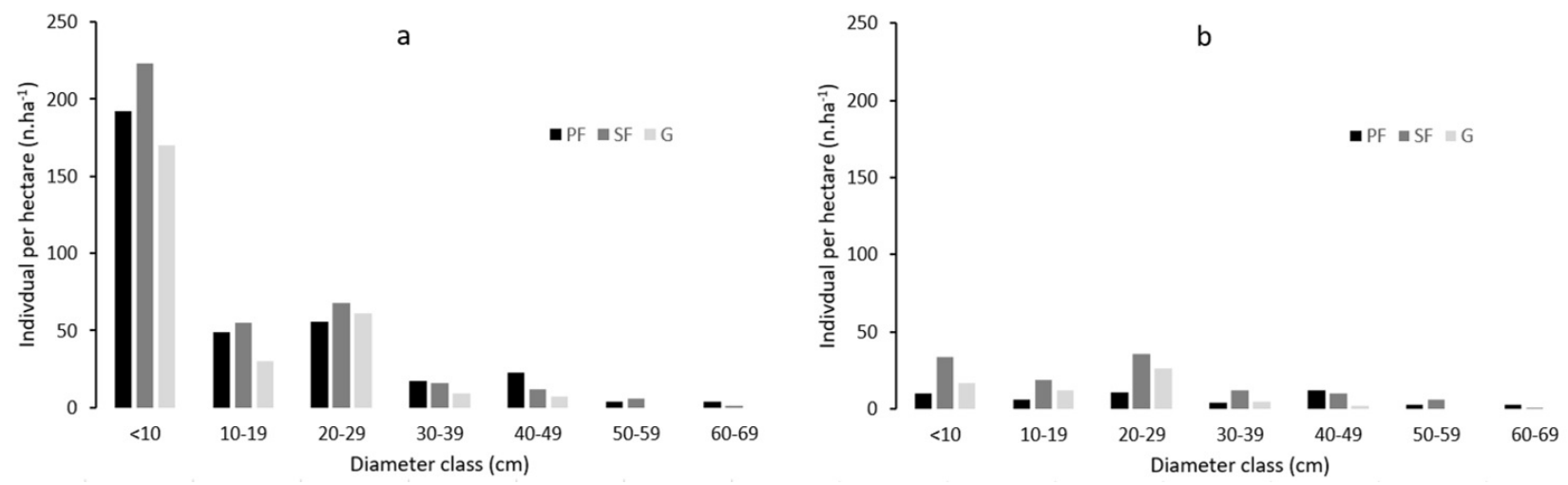

Figure 6. The destruction of individuals of tree species against diameter class ( $\mathrm{cm}$ ) in three habitats of Buah Hitam (a). Distribution of Buah Hitam individuals based on diameter class $(\mathrm{cm})(\mathrm{b})$.

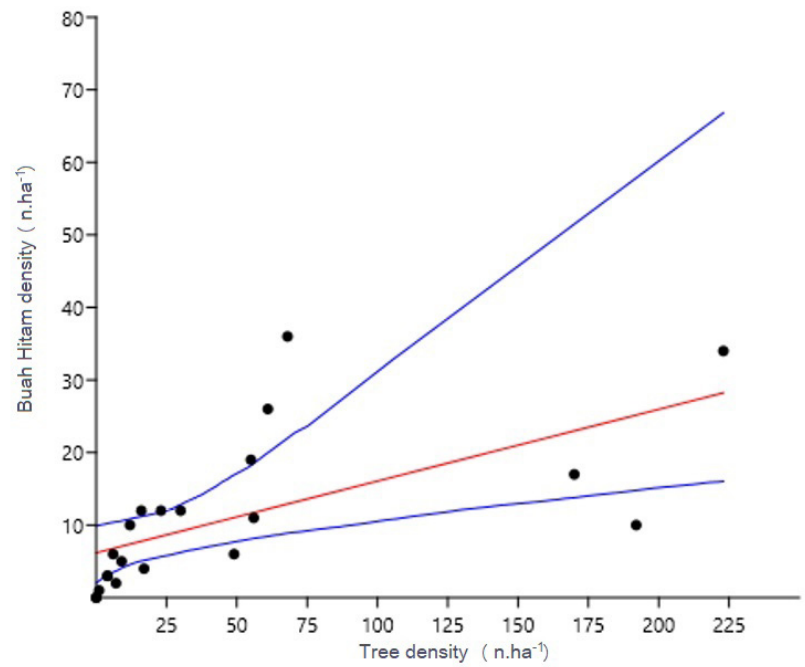

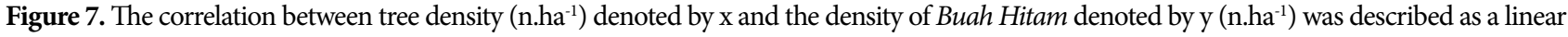
model with equation $y=0.0988 x+6.1845$ and coefficient of determination $\left(R^{2}\right)=0.3908$. The $95 \%$ confidence limits (blue lines) for the average (red line) are shown in the graph. That is a tendency that the number of Buah Hitam increased with increasing tree density in the areas.

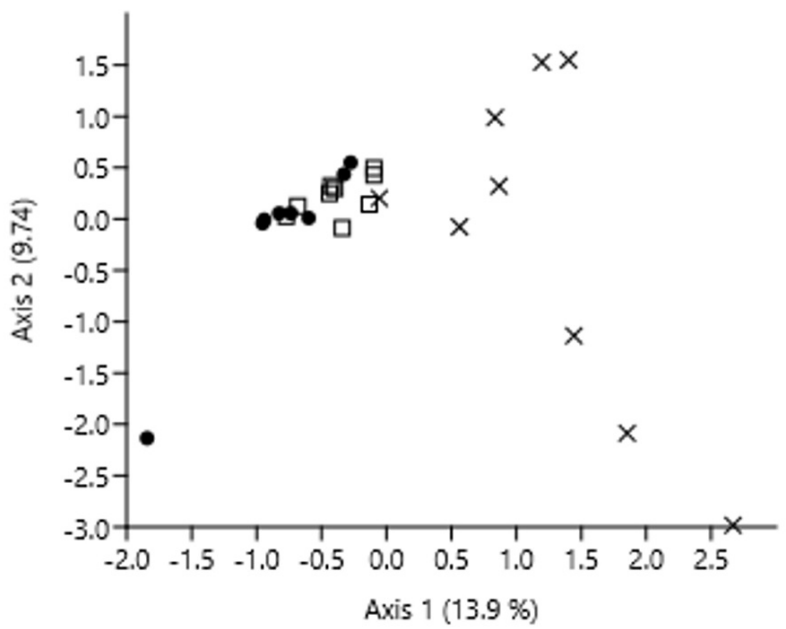

Figure 8. Correspondence Analysis of plot distribution in primary forest (x) and secondary forest ( $\square$ ), and Garden $(\bullet)$ to show the pattern of tree communities. 


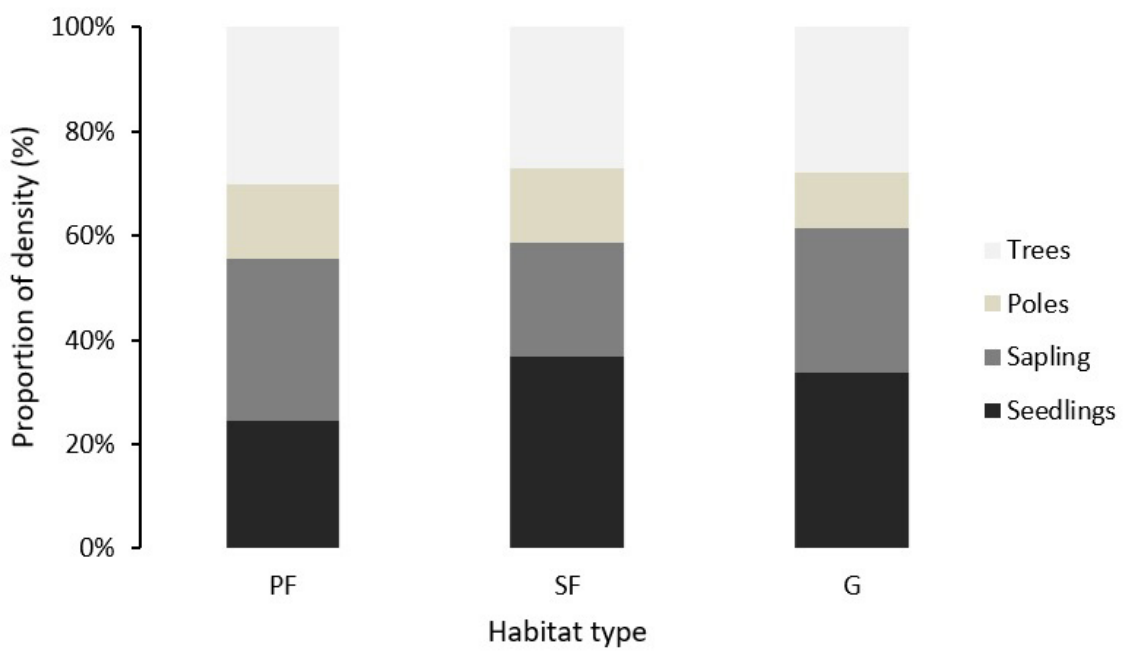

Figure 9. Density proportion of seedlings, saplings, poles, and trees in primary forest (PF) and secondary forest (SF), and Garden (G).

The structure of tree species under three habitats can be explained by specifying the density ratio. Then, the distribution of tree species in the three habitats was described by seedlings, saplings, poles, and trees as shown in Figure 9. The number of seedlings was highest in secondary forest and the lowest number of seedlings was present in primary forest. The saplings were abundantly in the primary forest followed by garden and secondary forest, respectively. The larger individuals were described using poles and trees, as the number of both seems to be more or less similar among the three habitats.

\section{DISCUSSION}

The species composition of the trees in the habitats of Buah Hitam showed that variation in the primary forest, in the secondary forest, and the garden. The primary forest here is characterized as a mixed tropical forest with many species (Murdjoko et al., 2021). This biotic state in the primary forest was similar to that of the secondary forest, especially the composition of the tree species, while the garden contains fewer tree species compared to the two forests (Murdjoko et al., 2017; Tawer et al., 2021). The secondary forest is a result of the swidden activity where the rotation of agriculture was not studied intensively and the cycle is unclear during traditional crops. The ex-field of crops were normally left recovering itself during post-swidden. Therefore, the composition of species differed from the primary forest by the decreasing number of tree species. Subsequently, the garden was created through the establishment of a settlement in an area that previously functioned as a secondary forest and the local communities have been living there for generations. Gardening is about gathering useful plants, but they have spent some time planting the vegetation extensively while making a living from the forest and other natural resources (Ungirwalu, 2019). Hence, there has been some composition of tree species growing in the garden.

The density of tree species in all three habitats formed an abundance of small individuals as a dynamic population process in the tropical forest. The habitats formed microclimate conditions such as sunlight, density, and humidity and have a consequence on the wood character of each tree species (Camargo \& Marenco, 2017; Candido et al., 2019; Cordeiro et al., 2020; Zhang et al., 2021). Regardless of the species compositing, the regeneration of tree species in three habitats of Buah Hitam was successfully established during the natural process. The vertical structure relationship in the three habitats of Buah Hitam includes seedlings, trees, poles, and trees, where small individuals (seedlings and trees) were mostly larger than larger individuals (poles and trees) indicating as natural regeneration (Pamoengkas et al., 2019; Sales de Melo et al., 2019; Siminski et al., 2021)

The individuals of Buah Hitam have a strong relationship with other tree species in which the ten species were mostly present along with Buah Hitam (Figure 5). The dendrogram was executed to see how many species had heterospecific associations forming the tree community. The six species, namely Artocarpus heterophyllus, Citrus sp, Sterculia schliebenii, Clerodendrum sp, Artocarpus altilis, and Premna corymbosa mostly grow in the secondary forest and garden. The formation of the Buah Hitam tree community was mainly a result of human activity, while the Buah Hitam seed was used less 
when it was used in the ethnobotanical process, which left the number of seeds on the ground, especially in the secondary forest and garden. This was a part of traditional activity including the Buah Hitam utilization. Besides, the reproductive season of this species is annual, and therefore the availability of Buah Hitam has met the local people's needs particularly as nutrient supply. This may be the reason that the correlation between tree density and Buah Hitam density was about $39 \%$ where the increase of tree density positively affects the density of Buah Hitam. It was imperative to explain that the tree community of Buah Hitam habitats formed generally two groups viz. mainly primary forest and both secondary forest with garden (Figure 8).

The regeneration of Buah Hitam was mainly influenced by anthropogenic factors, especially in secondary forests and gardens. Thus, the number of Buah Hitam individuals with a diameter of less than $30 \mathrm{~cm}$ in the secondary forest and garden compared to those in the primary forest are shown in Figure 6b. The Buah Hitam in primary forest regenerated naturally for decades and is, therefore, the less number of small individuals. Thus, the regeneration process depends on the natural dynamic (Tuan \& Dinh, 2020) as seed dispersal was predictably conducted by bats or other wildlife (Naniwadekar et al., 2015; Seidler \& Plotkin, 2006). Some of the seeds have been moved away from the parent trees creating a negative-conspecific association (Murdjoko et al., 2016, 2020). Based on observation and interviews that the Buah Hitam was frequently taken by bats as food, the locals used traditional pest control known as apiaimi and kabareru, which was part of the traditional ecological knowledge in the area (Ungirwalu et al., 2017). The traditional pest control was mostly conducted in the secondary forest where the distance from their home was taken into consideration. Only a few have implemented the traditional pest control in the primary forest by having specific reasons such as the abundance of harvestable fruits from trees. In the garden, the Buah Hitam trees rarely experienced pest activity such as bats. Consequently, the Buah Hitam tress in primary forest functioned as the food supply for wildlife.

\subsection{Strategic implication for sustainable forest management}

Strategies of sustainable management acquired from traditional conservation concept by conserving the socio-culture of ethnic Wandamen. Consequently, the local people would still conduct the sustainable management of utilization. Then, the habitat of Buah Hitam can be used to develop traditional protection concepts, especially in the primary forest. The majority of the local population continues to believe that the dynamics are limiting natural resources in order to preserve the forest ecosystem. This research revealed that the primary forest has been preserved as a natural place and the local people have utilized the part of the secondary forest as a result of shifting cultivation. Although their livelihood fully depends on natural forest, they only worked in secondary forest and garden as swidden agriculture, as their ancestors carried out in a similar field. However, extensive research regarding swidden and conservation is less known, yet the swidden has been conducted for generations (Fujiki et al., 2017; Mukul \& Herbohn, 2016).

Thus, this research suggested that the traditional concept of conservation should be considered by the government to view the development on a conservation basis, as formally stated in the declaration (Cámara-Leret, Schuiteman, et al., 2019; Indrawan et al., 2019). Involving the local community in regional development is mandatory in order to acquire the traditional concept that supports the sustainable management of natural resources, especially forests. The government has reviewed the Mount Wondiwoy nature reserve, but on the edge of the nature reserve, consideration should be given to the case where the government is required to establish a forest based on local knowledge as consensus programs. In brief, by delineating the forest area to create traditional zones, this can be the possible program for conservation particularly in-situ conservation programs, and conduct the regular monitoring of species in this area particularly vegetation.

\section{ACKNOWLEDGMENTS}

This research is part of the "Penelitian Terapan Unggulan Perguruan Tinggi RISTEKDIKTI 2021”. The author's expresses profound gratitude to Teluk Wondama Regency, Fakultas Kehutanan Universitas Papua, Balitbangda Provinsi Papua Barat, and Kepala Biro Administrasi Pembangunan Provinsi Papua Barat for permit, field guide, supporting. We are extremely grateful to anonymous reviewer(s) for improving this work.

\section{SUBMISSION STATUS}

Received: 26 May. 2021

Accepted: 30 June. 2021

Associate editor: João Vicente Latorraca

\section{CORRESPONDENCE TO}

\section{Agustinus Murdjoko}

Universitas Papua, Fakultas Kehutanan, Jalan Gunung Salju Amban,

Manokwari 98314, Papua Barat, Indonesia.

e-mail: agustinus.murdjoko.papua@gmail.com 


\section{REFERENCES}

Armatas CA, Venn TJ, McBride BB, Watson AE, Carver SJ. Opportunities to utilize traditional phenological knowledge to support adaptive management of social-ecological systems vulnerable to changes in climate and fire regimes. Ecology and Society 2016; 21(1).

Badan Pusat Statistik Kota Teluk Wondama. Kabupaten Teluk Wondama Dalam Angka 2019 2019) | i.

Cámara-Leret R, Dennehy Z. Indigenous Knowledge of New Guinea’s Useful Plants: A Review. Economic Botany 2019; 73(3): 405-415.

Cámara-Leret R, Raes N, Roehrdanz P, De Fretes Y, Heatubun CD, Roeble L, et al. Climate change threatens New Guinea's biocultural heritage. Science Advances 2019; 5: 1-8.

Cámara-Leret R, Schuiteman A, Utteridge T, Bramley G, Deverell R, Fisher LA, et al. The Manokwari declaration: Challenges ahead in conserving $70 \%$ of Tanah Papua's forests. Forest and Society 2019; 3(1):148-51.

Cámara-Leret R., Frodin DG, Adema F, Anderson C, Appelhans MS, Argent G, et al. New Guinea has the world's richest island. Nature 2020; 584: 579-583.

Camargo MAB, Marenco RA. Tree growth over three years in response to monthly rainfall in central Amazonia. Dendrobiology 2017; 78:10-7.

Candido ES, Ramos MBC, Martins R, Messias MCTB. Flora and vegetation in different physiognomies of a mussununga in southeastern Brazil. Floresta e Ambient 2019; 26(3).

Colwell RK, Mao CX, Chang J. Interpolating, Extrapolating, And Comparing Incidence-Based Species Accumulation Curves. Ecology 2004; 85(10): 2717-2727.

Cordeiro J, Zwiener VP, Curcio GR, Roderjan CV. Edaphic Drivers of Community Structure and Composition in a Mixed Ombrophilous Forest. Floresta e Ambient 2020; 27(2):1-12.

Fatem SM, Djitmau DA, Ungirwalu A, Wanma OA, Simbiak VI, Benu NMH, et al. Species diversity, composition, and heterospecific associations of trees in three altitudinal gradients in Bird's Head Peninsula, Papua, Indonesia. Biodiversitas 2020; 21(8): 3596-3605.

Fujiki S, Nishio S, Okada K, Nais J, Kitayama K. Plant communities and ecosystem processes in a succession-altitude matrix after shifting cultivation in the tropical montane forest zone of northern Borneo. Journal of Tropical Ecology 2017; 33(1):33-49.

Gaveau DLA, Santos L, Locatelli B, Salim MA, Husnayaen H. Forest loss in Indonesian New Guinea : trends, drivers, and outlook. bioRxiv 2021; 0-3.

Hammer $\varnothing$, Harper DA, Ryan PD. PAST: paleontological statistics software package for education and data analysis. Palaeontologia Electronica 2001; 4(1): 9 pp.

Indrawan M, Sumule A, Wijaya A, Kapisa N, Wanggai F, Ahmad $\mathrm{M}$, et al. A time for locally driven development in Papua and West Papua. Development in Practice 2019; 29(6):817-23.

Jung M, Dahal PR, Butchart SHM, Donald PF, De Lamo X, Lesiv M, et al. A global map of terrestrial habitat types. Scientific Data 2020; 7(1): 1-8.
Kuswandi R, Sadono R, Supriyatno N, Marsono D. Keanekaragaman Struktur Tegakan Hutan Alam Bekas Tebangan Berdasarkan Biogeografi di Papua. Jurnal Manusia dan Lingkungan 2015; 22(2): 151-159.

Levi T, Barfield M, Barrantes S, Sullivan C, Holt RD, Terborgh J. Tropical forests can maintain hyperdiversity because of enemies. Proceedings of the National Academy of Sciences of the United States of America 2019; 116(2): 581-586.

Lugo AE. The emerging era of novel tropical forests. Biotropica 2009; 41(5) 589-591.

Mukul SA, Herbohn J. The impacts of shifting cultivation on secondary forests dynamics in tropics: A synthesis of the key findings and spatio temporal distribution of research. Environmental Science and Policy 2016; 55:167-77.

Murdjoko A, Djitmau DA, Ungirwalu A, Sinery AS, Siburian RHS, et al. Pattern of tree diversity in lowland tropical forest in Nikiwar, West Papua, Indonesia. Dendrobiology 2021; 85: 78-91.

Murdjoko A, Jitmau MM, Djitmau DA, Mardiyadi Z, Rumatora A, Mofu WY, et al. Heterospecific and conspecific associations of trees in lowland tropical forest of New Guinea. Biodiversitas 2020; 21(9): 4405-4418.

Murdjoko A, Marsono D, Sadono R, Hadisusanto S. Plant Species Composition and Their Conspecific Association in Natural Tropical Rainforest, South Papua. Biosaintifika: Journal of Biology Biology Education 2016; 8(1): 33.

Murdjoko A, Marsono D, Sadono R, Hadisusanto S. Recovery of residual forest ecosystem as an impact of selective logging in South Papua: An ecological approach. Biotropia 2017; 24(3): 230-245.

Naniwadekar R, Shukla U, Isvaran K, Datta A. Reduced hornbill abundance associated with low seed arrival and altered recruitment in a hunted and logged tropical forest. PLoS ONE 2015; 10:3; e0120062.

Page T, Murphy ME, Mizrahi M, Cornelius JP, Venter M. Sustainability of wood-use in remote forest-dependent communities of Papua New Guinea. Forest Ecology and Management 2016; 382: 88-99.

Paiva PFPR, de Lourdes Pinheiro Ruivo M, da Silva Júnior OM, de Nazaré Martins Maciel M, Braga TGM, de Andrade MMN, et al. Deforestation in protect areas in the Amazon: a threat to biodiversity. Biodiversity and Conservation 2020; 29(1): 19-38.

Pamoengkas P, Zamzam A, Dwisutono A. Vegetation Recovery of Logged-over Dipterocarp Forests In Central Kalimantan, Indonesia. Floresta e Ambient 2019; 26(3):1-11.

Pan Y, Birdsey RA, Phillips OL, Jackson RB. The Structure, Distribution, and Biomass of the World's Forests. Annual Review of Ecology, Evolution, and Systematics 2013; 44(1): 593-622.

Peet RK. The Measurement of Species Diversity. Ecology 2007; 5(1974; 285-307.

Sales de Melo CLSM, Caraciolo Ferreira RL, da Silva JAA, Herrera Machuca MÁ, Gutierrez Cespedes GH. Dynamics of dry tropical forest after three decades of vegetation suppression. Floresta e Ambient 2019; 26(3):1-12.

Seidler TG, Plotkin JB. Seed dispersal and spatial pattern in tropical trees. PLoS Biology 2006; 4(11): 2132-2137.

Shannon CE. A Mathematical Theory of Communication. The Bell System Technical Journal 1948; 27(4): 623-656. 
Siminski A, Zambiazi DC, dos Santos KL, Fantini AC. Dynamics of Natural Regeneration: Implications for Landscape Restoration in the Atlantic Forest, Brazil. Frontiers in Forests and Global Change 2021; 4:1-15.

Slik JWF, Franklin J, Arroyo-Rodríguez V, Field R, Aguilar S, Aguirre $\mathrm{N}$, et al. Phylogenetic classification of the world's tropical forests. Proceedings of the National Academy of Sciences of the United States of America 2018; 115(8): 1837-1842.

Spellerberg IF., Fedor, P. J. A tribute to Claude-Shannon (19162001) and a plea for more rigorous use of species richness, species diversity and the "Shannon-Wiener" Index. Global Ecology and Biogeography 2003; 12(3): 177-179.

Tawer P, Maturbongs R, Murdjoko A, Jitmau M, Djitmau D, Siburian $\mathrm{R}$, et al. Vegetation dynamic post-disturbance in tropical rain forest of bird's head peninsula of west papua, indonesia. Annals of Silvicultural Research 2021; 46(1): 48-58.

Tuan NT, Dinh TT. Growth performance of dipterocarpus alatus and hopea odorata in degraded secondary forest land in Southern Vietnam. Dendrobiology 2020; 83:60-67.

Ungirwalu A, Awang SA, Maryudi A, Suryanto P. Pengelolaan Adaptif Pemanfaatan Buah Hitam (Haplolobus monticola Blumea) Etnis Wandamen-Papua. Jurnal Manusia dan Lingkungan 2016; 23(2): 266.

Ungirwalu A, Awang SA, Murdjoko A. Potensi Pengembangan Agroforestri Tumbuhan Buah Hitam Berbasis Pengetahuan Lokal Etnis Wandamen-Papua : Prospek Perhutanan Sosial Di Papua Barat. In Prosiding Seminar Nasional Silvikultur II : Pembaharuan Silvikultur untuk mendukung Pemulihan Fungsi Hutan menuju Ekonomi Hijau 2014; 268-274.
Ungirwalu A, Awang SA, Suryanto P, Maryudi A. Konstruksi HutanBudaya : Skenario Pengelolaan Sumberdaya Alam Adaptif Hasil Hutan Bukan Kayu (HHBK) Berbasis Masyarakat Adat Di Papua Barat (Dissertation) 2018.

Ungirwalu A, Awang SA, Suryanto P, Maryudi A. The ethno-technoconservation approach in the utilization of Black Fruit (Haplolobus sp.) by the Wandamen ethnic of Papua, Indonesia. Biodiversitas 2017; 18(4): 1336-1343.

Ungirwalu A. Tipologi Dan Komposisi Kebun-Pekarangan Etnis Wandamen Dalam Mendukung Sistem Konservasi Dan Pelestarian Potensi Lokal Masa Depan. In Prosiding Seminar Nasional MIPA UNIPA IV tahun 2019 2019; (29-43).

Villaseñor JL, Ortiz E, Campos-Villanueva A. High Richness of Vascular Plants in the Tropical Los Tuxtlas Region, Mexico. Tropical Conservation Science 2018; 11.

Vleminckx J, Drouet T, Amani C, Lisingo J, Lejoly J, Hardy OJ. Impact of fine-scale edaphic heterogeneity on tree species assembly in a central African rainforest. Journal of Vegetation Science 2015; 26(1): 134-144.

Whittaker RH. Evolution and Measurement of Species Diversity. Taxon 1972; 21(2): 213-251.

Zhang Z, Jin G, Feng Z, Sun L. Provenance-specific climate sensitivity of Pinus massoniana - a multi-environmental trial in subtropical China. Dendrobiology 2021; 85:3-18.

Zimmerman BL, Kormos CF. Prospects for Sustainable Logging in Tropical Forests. BioScience 2012; 62(5): 479-487. 